\title{
Department of Theology of the Academy of Catholic Theology (ATK) as a Dynamic Scientific Centre*
}

Let me start by remarking that in the first decades of our university's existence, the boundaries between its departments divided students and employees incomparably to a much lesser extent than at present. It is enough to recall that for many years the chronicle published in almost every issue of the STV recorded the most important events that took place at all three departments at that time, not only at the Theological Department.

This common sense of unity of our Alma Mater, much deeper than at present, resulted not only from the fact that its three departments - theological, philosophical and legal - were created from one (though a double, Warsaw and Kraków) Theological Department. First of all, ATK was a small university, the number of its students could not exceed the limits, which were set externally by the state authorities. The small size favoured the feeling that we were one community of professors and students.

The pressure of reality, as well as the gradual weakening of the communist system, made the university slowly but steadily expand and develop. Ultimately, the Theological Department of ATK turned out to be so large that a large part of it - church history, art history and patrology, and thus the disciplines deeply related to theology - in 1987 were transferred to the newly created Department of Church Historical and Social Sciences. In my opinion (and not only mine), the negative effects of this separation are felt in both our departments to this day.

I mention this fact because it is impossible to refer to these three disciplines in this, unfortunately cursory, study. I will omit, however, because this is a subject discussed by other authors in this issue of the STV, the history of biblical studies, catechetics, homiletics, pastoral theology and missiology that is developing brilliantly in our department.

* STV 51(2013)1. 


\section{Dogmatic Theology}

Coryphaeus of dogmatic theology at ATK was Rev. Ignacy Różycki (1911-1983), who at the time of the liquidation of theological faculties (1954) was a professor at the Jagiellonian University. I cannot say how one should interpret the information given in the Catholic Encyclopedia (volume 17 col. 499), that he worked in ATK only until 1957. When I was a student at ATK, I participated in his lectures on dogmatic theology in the 1968/69 academic year. In the pages of the journal ATK "Studia Theologica Varsaviensia" he published his articles, sometimes very extensive (e.g. the problem of internal non-contradiction and usefulness of the Scheeben's doctrine of grace of adoption as son, STV vol. 4, 1966 No. 2 pp. 233-268, vol.5, 1967 no. 1 pp. 73-150). At the Theological Department of ATK, he was the supervisor of doctoral students (e.g. in the seventies, excellent doctoral dissertations under his guidance were written and defended by Jerzy Kotara, Tadeusz Dionizy Łukaszuk and Engelbert Gorywoda). It is true that the Rev. Różycki never moved to Warsaw, however - according to my knowledge - he tried to attend the lectures diligently.

John Paul II always gratefully mentioned him as his professor. He was the supervisor of the master's thesis of the Rev. Karol Wojtyła (entitled The Concept of the Centre of the Unification of the Soul with God in the Context of the Doctrine of the Saint John of the Cross). From October 27, 1965, he was a Council expert; he was involved in the work on the Declaration on Religious Freedom and the Pastoral Constitution on the Church in the Modern World. Later, the Rev. Różycki, in a sense, passed a report on his involvement, in a lecture given at ATK on May 17, 1966, entitled My experience resulting from the conciliar and scientific contacts during my stay abroad. The History of Dogmas Department was directed by Rev. Henryk Bogacki SJ (1924-1993), who concentrated his research on ecclesiology, but he rendered merit to Polish theology primarily as an extremely energetic director of the ATK publishing house. He saved the quarterly "Collectanea Theologica" for Polish theology, when it ceased to be issued, and for several decades (1966-1990) he was its editor-in-chief, but thanks to his extraordinary energy and organizational talent, the ATK publishing house provided Polish researchers with hundreds of priceless scientific publications, among others within such series as "Pisma starochrześcijańskich pisarzy," "Studia antiquitatis christianae," "Textus et studia theologiae in Polonia excultae spectantia," "Opera philosophorum medii aevi," "Studia teologiczno-dogmatyczne," "Polskie studia ascetyczne," "Studia z biblistyki," "Zeszyty misjologiczne," "Posoborowe ustawodawstwo kościelne," "Muzyka religijna w Polsce," "Studia z historii Kościoła w Polsce," "Bibliografia historii Kościoła w Polsce," "Polska bibliografia nauk kościelnych," "Z zagadnień filozofii przyrodoznawstwa i filozofii przyrody." 
[3] Department of Theology of the Academy of Catholic Theology (ATK) as a Dynamic Scientific Centre

In the 1970s, the circles of dogmatic theologians at ATK were led by Rev. Andrzej Zuberbier (1922-2000). In September 1971, just after his post-doctoral 'habilitation', he was elected the first chairman of the Dogmatic Section of Polish Theologians. As he performed this function well he was elected twice more for subsequent terms. As a younger colleague from the same university, I was elected secretary of this section and to a greater or lesser extent participated in the preparation of subsequent symposia held by the section during his chairmanship. These symposia were indeed considered real events. Already their themes - just as I can recall some of them now - confirm the intellectual sophistication of our chairman: Theological Hermeneutics, Contemporary trends in Christology, In search of new models of the lecture on God, Polish Theology - does it have its specificity? Indeed, Zuberbier was able to take care of the best lecturers, and he valued the interdisciplinarity, both intra-theological and that understood more broadly. He was a theologian, whose articles were often published in "Tygodnik powszechny," "Znak" or "Więź."

From 1970, dogmatics at ATK were taught by Rev. Edward Ozorowski, the future archbishop of Białystok, an ecclesiologist who later moved to the Research on Family Institute. Also in 1970, Rev. Jacek Salij began to teach dogmatics at ATK, trying not to hide his enthusiasm to St. Thomas Aquinas' thought.

In the years 1971-1993, a group of dogmatic theologians at ATK including Rev. Alfons Skowronek, deeply aware of what is currently happening in German theology, a theologian with vivid ecumenical interests. In 1972, Rev. Lucjan Balter joined the group (1936-2010), an expert particularly in the field of ecclesiology, Mariology, Josephology and eschatology, the editor-in-chief of the Polish edition of "Concilium", and later "Communio", yet these journals were published outside ATK.

\section{Moral Theology}

Moral theology was characterized by the fact that academic staff dealing with this discipline underwent a generational exchange during the first years of existence of ATK. Rev. Władysław Wicher (1888-1969), author of Fundamentals of Moral Theology, published after leaving our university, left ATK in 1957. Rev. Stanisław Huet, author of the highly popular two-volume work entitled The sacrament of penance in the light of theology and psycho-hygiene, died in 1961. The last veteran from the time when theology was taught at universities, Rev. Walenty Urmanowicz (1898-1969), died eight years later.

Thus, the main trends in moral theology in ATK were henceforth set by young researchers such as: Rev. Stanisław Olejnik (born in 1920), who tried 
to practice moral theology in a personalist spirit, which is best demonstrated by the very title of his opus vitae: In response to the gift and calling of God, outline of moral theology. Here it is worth remembering that Rev. Stanisław Olejnik was a member of the International Theological Commission in Rome in 1968-73.

To other moral theologians, who started their scientific activity at the Faculty of Theology of ATK in the late sixties, one should include Rev. Bogusław Inlender (1923-2006), a scholar particularly sensitive to the methodological problems associated with this discipline; Rev. Jan Pryszmont (1919-2007), focusing his research activity on the moralists of the Orthodox Church; Rev. Helmut Juros (born 1933), who before decided to concentrate mainly on organizing at ATK a study of Catholic social science and political science, was especially interested in the so-called "independent ethics" - the result of this search is, among others his work entitled Moral Theology or Theological Ethics? A Study on the Metatheology of Morality. Thanks to the latter, the theologians working at ATK developed intense relationships with German moralists. During spring 1972, our university was visited by such eminent representatives of German theology as Franz Bockle from Bonn (with a lecture entitled "Proprium of Christian ethics"), J.G. Ziegler from Mainz (with a lecture entitled "Is there a Christian-specific ethics?") and Bernard Haring with a whole series of lectures. Of course, in response to these visits, our theologians in turn travelled with their lectures to German universities. The priests Helmut Juros, Jan Pryszmont and the prematurely deceased Tadeusz Sikorski participated particularly often in this academic exchange.

\section{Fundamental Theology}

Initially, this discipline at ATK definitely took the form of apologetics, to the extent that the term Warsaw School of Apologetics was created, whose creator and head was Rev. Wincenty Kwiatkowski (1892-1972), author of the monumental Total Apologetics. The following episode from my own biography may confirm the fact that great importance was attached at the Faculty of Theology of the ATK to this shape of apologetics as somewhat to the department's hallmark. I started studies at this department in 1968 after obtaining a BA in theology at another university, but I did not have the degree of Master of Theology necessary to do my PhD thesis, therefore, in order to obtain it I started studying at ATK. Here my undergraduate degree, of course, had been approved, but I had to complete the ex universa theologia examination in the field of apologetics.

There was no other discipline at the Theological Department, which would be so univocally focused (also after his death) around one master, Rev. 
[5] Department of Theology of the Academy of Catholic Theology (ATK) as a Dynamic Scientific Centre

Kwiatkowski, initially Dean of the department, and in the years 1956-1965 its rector. The following professors belonged to the Warsaw School of Apologetics: above all, the closest collaborator of Rev. Kwiatkowski, Ryszard Paciorkowski (1908-1981) who, starting from his initial interests in the apologetics of the ancient Church, later focused on working on his magnum opus entitled Examples of paranormal healings in modern Christianity; Rev. Władysław Hładowski (1913-2004), author of the Outline of Apologetics; Rev. Tadeusz Gogolewski (1921-2003), who devoted much of his attention to popularizing apologetic of the Western Church (J.S. Drey, R. Latourelle, H. Bouillard, A.M. Javier); Rev. Wojciech Tabaczyński (born 1923), researcher of Easter Christophanies and revelations of Virgin Mary; Józef Myśków (1927-1988), author of a book on religious awareness of Jesus of Nazareth.

\section{Disciplines that Existed at the Theological Department before 1987}

In 1987, the history of the Church, history of art and patrology were transferred to the newly created Department of Church Historical and Social Sciences from the Theological Faculty of the ATK. As for the history of the Church, whose leading representative in our department was Rev. prof. Hieronim Eugeniusz Wyczawski (1918-1983), it is enough to mention the most important accomplishments of our historians, the monumental 8-volume Dictionary of Polish Catholic Theologians, vol. 1-7: Warsaw 1981-1983; vol.8: Warsaw 1995.

However, the faculty of history of art was directed by Rev. prof. Janusz Pasierb (1929-1993), poet, essayist, researcher extremely sensitive both to the theological dimension of works of art and artistic trends, as to their general cultural context. He enjoyed great authority in literary and artistic circles. His younger colleagues were prof. Zbigniew Bania (born 1946), researcher of architectural history, and Rev. Stanisław Kobielus (born 1939), author of, among others, book entitled Man and the Garden of Eden in the religious culture of the Middle Ages. Patrology was developing dynamically in our department, whose leading representatives were Rev. prof. Emil Stanula (1935-1999) and Rev. prof. Wincenty Myszor (born in 1941). They initiated the publishing series of the "Writings of Old-Christian Writers" and by 1987, that is until they left our department, they managed to publish as many as 43 volumes of this series. Rev. Stanula particularly dealt with the theology of Saint Hilary of Poitiers, and the works of this Doctor of the Church translated by him - On the Holy Trinity, Commentary on the Gospel of Saint Matthew and the Treaty on Mysteries - were 
published after his death. However, during his entire stay at our department Rev. Myszor worked intensively on the ancient Gnostic texts; translations of the Gnostic texts prepared by him, along with the comments were published regularly in the STV in 1971-1987. In addition, he is considered the most outstanding Polish expert in the works of St. Irenaeus from Lyon.

\section{Scientific Character of the Theological Department of ATK}

Today, it is easy to overlook the fact that in Poland there were only two theological departments (at the ATK and KUL, because the scientific relations with the ChAT were minimal), and their significance for Polish theology was significantly different than at present. The professors of both universities were practically doomed to maintain intense mutual relations if only due to the necessity of the presence of a reviewer from another university during every defence of doctorate and postdoctoral dissertations. Also, when symposia were organized, speakers were almost always first sought among the professors of the fraternal department. This fact must be remembered if one wants to present the importance of this faculty to the scientific status of Polish theology. It is obvious that it goes beyond the significance of the scientific achievements of the professors mentioned here, even if it is considerable and truly outstanding. After all, at least some habilitation and doctoral dissertations, and sometimes also master's theses, which were prepared at the theological department of ATK, are scientifically outstanding, and sometimes even priceless.

The symposia organized in this Department surely contributed to the development of theological thought in Poland. It is impossible to list them all. It is also worth noting that the most prominent theologians also visited our Department, and their lectures always gathered crowds of listeners. For example, on June 1, 1966 our department was visited by Yves Congar, who presented the lecture entitled Fundaments of theology of the laity. On May 16, 1970 we hosted Karl Rahner with a lecture entitled The starting point of modern theology, while on May 24 and 25, several lectures were presented by Bernard Haring, the then famous expert in moral theology, and on October 13, 1975 our guest was JeanHerve Nicolas, a dogmatist from Freiburg. Of course, it is impossible to list all the symposia and guests. In a word, we all tried to make it obvious for our students that a theological department would be inauthentic place if it did not try to be a dynamic scientific centre.

Department of Theology of The Academy of Catholic Theology: a dynamic scientific Centre. 